\title{
O que faz a diferença entre a linguagem rica e a linguagem pobre? ${ }^{12}$
}

\author{
What makes de difference between the rich and poor language?
}

\section{José Morais}

UNESCOG - CRCN - Université Libre de Bruxelles - Bélgica

\begin{abstract}
Resumo: A linguagem é considerada neste artigo como sendo, simultaneamente, um produto e um instrumento das grandes desigualdades sociais e culturais que caracterizam as sociedades humanas ditas civilizadas. A invenção da escrita conduziu ao desenvolvimento da linguagem letrada - a literacia -, mas sobretudo nas classes sociais privilegiadas. Tal como a linguagem oral, a literacia é uma capacidade cognitiva, ao mesmo título que percepção, atenção, memória, funções executivas ou de controle, pensamento, raciocínio. São aqui revistas, resumidamente, algumas das evidências da influência da literacia nestas outras capacidades cognitivas. A consequência da dinâmica suscitada pelo desenvolvimento da literacia e das suas múltiplas manifestações em sociedades que já eram muito desiguais é de fomentar cada vez mais a radicalização da dimensão riqueza-pobreza. É importante reconhecer que esta dimensão, habitualmente utilizada apenas em referência aos bens materiais, também afeta as capacidades cognitivas e, por conseguinte, a "mente", isto é, o sistema organizado dos processos mentais.
\end{abstract}

Palavras-chave: linguagem oral, linguagem letrada, literacia, desigualdades sociais, desigualdades educacionais, mente, capacidades cognitivas, pensamento, raciocínio.

Abstract: Language is considered here as being both a product and an instrument of the huge social and cultural inequalities characterizing the so-called civilized human societies. The invention of writing led to the development of literate language - literacy -, but mainly in the privileged social classes. Like spoken language, literacy is a cognitive capacity, as so are perception, attention, memory, executive or control functions, thinking and reasoning. Here, is succinctly reviewed some of the evidence for the influence of literacy on these cognitive capacities. One of the main consequences of the dynamic entailed by literacy development and its multiple outcomes in societies that were already unequal is an increasing radicalization of the richness-poorness dimension. It is of upmost importance to recognize that this dimension, frequently used in reference to material goods, also influences the cognitive capacities and, therefore, the "mind", in other words, the organized system of mental processes.

Keywords: spoken language, literate language, literacy, social inequalities, educational inequalities, mind, cognitive capacities, thinking, reasoning.

\footnotetext{
${ }^{1}$ Baseado, em grande parte, na keynote "What linguagem is ours?", apresentada no $50^{\circ}$ Congresso da Abralin, em Maceió, no dia 8 de maio de 2019. Embora essa keynote tivesse sido apresentada a título individual, o autor quer esclarecer que tanto ela como o presente artigo e muitos outros resultaram de uma interação constante de reflexão crítica com Régine Kolinsky. Assim, se o autor declarado assume a responsabilidade plena do presente artigo, não deixa por isso de reconhecer que nunca poderia tê-lo escrito se não tivesse havido entre nós dois uma longa - e igualitária - dinâmica de pensamento.

${ }^{2}$ A preparação deste artigo beneficiou da bolsa A.R.C. atribuída pela Comunidade Francófona da Bélgica a Régine Kolinsky, diretora da UNESCOG, para a realização do projeto "The Socio-Cognitive Impact of Literacy".
} 


\section{Introdução}

Há uma linguagem rica e uma linguagem pobre. A primeira é a dos letrados, a segunda a dos iletrados. Não se deve tomar aquela por linguagem dos ricos e esta por linguagem dos pobres, porque a coincidência não é total. No entanto, essa é, muito claramente, a tendência. É certo que a linguagem dos pobres, por, na sua grande maioria, não terem recebido instrução ou pouca, é uma linguagem pobre. Mas também é verdade que uns tantos ricos, por não terem aproveitado a instrução que receberam, utilizam uma linguagem pobre, sobretudo na fala.

Devo acrescentar que pobreza e riqueza, aplicadas quer à linguagem quer à posse de bens materiais, são os polos extremos de uma variável contínua e que, de qualquer modo, em proporções que variam muito segundo os países, muita gente não é pobre nem rica. Ambas as dimensões riqueza/pobreza, a referida aos bens materiais e a referida à linguagem, afastam-se muito da distribuição apelidada em estatística de "normal", que se caracteriza por ter o seu máximo no valor mediano e diminuir elegantemente e da mesma maneira para os extremos, com frequência cada vez mais raros nos valores mínimos e máximos.

Nos países ditos desenvolvidos, ou ricos, as pessoas que possuem enormes fortunas em bens materiais (incluindo valores convertíveis em dinheiro) são relativamente poucas, e a maioria das pessoas de classe média não é menos rica que aquelas em linguagem, isto por terem tido a oportunidade de receber, como os ricos, uma educação de alto nível. A situação é diferente nos países subdesenvolvidos porque neles os filhos de classe média-baixa, tal como os de classe pobre, têm muito menos oportunidades de receber uma instrução que lhes permita desenvolver uma linguagem rica.

Muitos de nós - com este "nós" refiro-me aos que lemos e escrevemos artigos, como este - ou seja, os letrados, possuímos duas formas de linguagem, a forma oral e a forma escrita, que nos permitem realizar 0 que definimos como compreensão (em situação de escuta ou de leitura) ou produção (em situação de fala ou de escrita). Os iletrados, esses, só possuem a forma oral. Curiosamente, não existem estatísticas nem sobre a linguagem oral (escuta ou fala) nem sobre a produção escrita. Por quê? Sem dúvida na base da ideia de que todos desenvolvem a linguagem falada do seu meio de origem social e do seu meio escolar (também socialmente determinado).

No que respeita à leitura e escrita, a segunda foi sempre considerada um instrumento de intervenção que seria perigoso desenvolver nas crianças e nos adolescentes que não pertençam às classes dominantes (às elites). Só a leitura tem sido objeto de inquéritos, porque é pela leitura que se recepciona a linguagem escrita e é importante que aqueles que não pertencem às elites possam compreender os textos religiosos e as instruções escritas quer para fins cívicos quer no seu trabalho profissional.

Assim, as estatísticas internacionais existentes só nos permitem examinar a pobreza e a riqueza da leitura, e com limitações, visto que os dados publicados distinguem os países, mas não as classes sociais no interior deles. A ideia de classe social é necessariamente tabu para a classe que, por ser a dominante, quer fazer difundir a ideia de que nas sociedades atuais deixou de haver classes.

Utilizarei aqui os dados do inquérito PISA, que se limita à compreensão em leitura, mas distingue sete níveis de habilidade (de 1a e 1b, os mais baixos, até 6). Aquele que lê ao nível 4 deve ser capaz de "compreensão precisa de textos longos ou complexos cujo conteúdo ou forma pode não ser familiar" (OECD, 2016a). Ora isso só é possível quando a leitura de palavras já se tornou hábil. Por quê? Porque justamente a leitura baseada em processos automáticos de reconhecimento das palavras escritas deixa livres os processos de controle cognitivo consciente para a "compreensão precisa" do texto. Obviamente, esse nível 4 de leitura requer mais do que o reconhecimento automático das palavras; ele requer também um nível suficiente de conhecimento do vocabulário utilizado e das matérias abordadas, de capacidade de análise sintática e de raciocínio. São 
exigências maiores em todos estes aspectos que justificam a atribuição dos níveis 5 e 6 em leitura.

Como assinalado em Morais e Kolinsky (2020, no prelo), o nível 4 só foi atingido, no PISA de 2015 (publicado em 2016), por 29,5\% dos adolescentes escolarizados, de 15 anos, dos países da OCDE (média sobre os resultados de cada país, portanto ignorando o tamanho das suas populações). Isto é, a leitura "minimamente rica" em termos de compreensão é apenas apanágio de 3 em 10 adolescentes dos países desenvolvidos. Foi o caso, por exemplo, dos EUA, da Alemanha e da GrãBretanha, países ricos em bens materiais mesmo se estes estão distribuídos muito desigualmente.

Outros países ricos, como o Canadá e a Finlândia, têm uma proporção de leitores no nível 4 ou acima superior a $40 \%$, o que é o caso também de alguns países ou regiões que não pertencem à OCDE, por exemplo Singapura e Hong-Kong (na China). Na América Latina, o Brasil é um dos países com menor proporção de leitores no nível 4 e acima: apenas 9\%, enquanto o Chile (da OCDE) está ligeiramente acima dos $30 \%$.

Será que houve melhoria no Brasil entre 2000 e 2015? Sim, houve, mas insuficiente, e ela pode ter resultado, não necessariamente de uma melhoria no ensino da leitura e da escrita, mas do esforço realizado pelos governos Lula, e mais geralmente do Partido dos Trabalhadores, para promover uma ascensão social das classes pobres incluindo uma maior ajuda à escola pública. Em 2000, tinham sido $56 \%$ os adolescentes escolarizados que ficaram abaixo do nível 2 , o que equivale a uma condenação a ficar iletrado funcional para toda a vida (apenas 20\% na média dos países). Em 2012, já só foram $49 \%$, voltando a subir (talvez em consequência da crise financeira de 2008) para 52\% em 2015. Quanto aos níveis mais elevados (5 e 6), eles tinham sido atingidos, em 2000, por menos de $0,5 \%$ dos adolescentes (9\% na média geral dos países) e subiram para 2\% em 2015.

Assim, no total das descidas dos níveis baixos e das subidas nos níveis altos, o saldo em melhoria global entre 2000 e 2015 foi de $5,5 \%$ e poderia ter sido melhor sem as consequências econômicas e políticas da crise de 2008. Tendo em conta que a situação econômica, social e política se reflete sempre na educação, e que ela tem degenerado no Brasil nos últimos anos, em particular sob o governo atual, o prognóstico dos próximos resultados (relativos a 2018 e sobretudo 2021) é muito inquietante. Há urgência em mudar de governantes e de rumo! Isso parece estar sendo sentido pela grande maioria dos professores e alunos.

Relativamente aos níveis mais baixos, note-se que, infelizmente, o PISA não inclui testes que permitam distinguir especificamente a leitura automática das palavras da sua leitura controlada e lenta, por decodificação. No entanto, é muito improvável que a leitura abaixo do nível 2 (o qual só exige "localizar um ou mais pedaços de informação (...) construindo significado numa parte limitada do texto") se baseie na leitura automática das palavras. Ora, como já disse, a média dos países da OCDE para os que leem abaixo do nível 2 (os pobres em leitura) é de $20 \%$. Um em cinco, é muito!

Em torno desta média, ligeiramente acima, estão países como a Itália, a França e a Áustria, e, ligeiramente abaixo, outros como Portugal, GrãBretanha e EUA. Em todos estes países cerca de 1/5 dos adolescentes que frequentam estabelecimentos de ensino são, portanto, pobres em leitura. $\mathrm{Na}$ América latina, se o Chile não faz boa figura (30\%), o Brasil, como já vimos, está muito pior.

A esmagadora maioria da pobreza leitora que caracteriza o Brasil contrasta de maneira flagrante com a riqueza em leitura - recordamos - de Singapura, Hong-Kong, Canadá e Finlândia, países que têm uma alta percentagem de minimamente "ricos" (diríamos que fazem parte, pelo menos, da classe média alta da leitura). De fato, são mais de $40 \%$, enquanto nos mesmos países a percentagem de pobres em leitura só ligeiramente ultrapassa os $10 \%$.

Resumindo, pode dizer-se que, enquanto nos países ricos e desenvolvidos, a proporção é, em termos de nível de leitura, de 4 "ricos" para um "pobre", no Brasil ela é de menos de "1 rico" para 
mais de "5 pobres". O drama não está tanto no fato de o Brasil ser ou não rico (ele até tem imensas riquezas naturais). Está sobretudo no fato de não se ter desenvolvido. E se não se desenvolveu é porque tem sido quase sempre dominado por uma elite de ricos em valores mercantis que entrega o país a quem governa no interesse dessa elite e não se preocupa com a educação e o enriquecimento do povo em matéria de linguagem oral e escrita.

É tempo de introduzir o termo de literacia. Mais adiante, ele será examinado mais amplamente na sua história e nos seus conteúdos. Por agora, assumamos que o conceito de literacia reúne três sentidos, a habilidade de ler e escrever, o seu impacto na linguagem oral, nas capacidades e nas atividades cognitivas, e a sua manifestação diversificada em domínios do conhecimento, da comunicação e da criação artística.

Antes de considerar o impacto da literacia na linguagem e na cognição humanas, apresentarei o contexto mais geral dos tipos de processos que condicionaram o aparecimento da linguagem e a emergência da literacia. $O$ aparecimento da linguagem deve ser apreciado com base num entendimento justo do que são processos biológicos e culturais, e a emergência da literacia tendo em conta a necessária diferenciação entre processos evolutivos e emergentes.

\section{Processos biológicos e culturais}

É de propósito que não utilizo, de chofre, os substantivos biologia e cultura. "Biologia" e "cultura" são abstrações nossas, da nossa história letrada. É difícil imaginar os Sapiens de há duzentos mil anos, depois de terem devorado uma boa peça de carne de um mamífero caçado nessa tarde, conversarem entre eles sobre as suas necessidades e os seus costumes falando de biologia e cultura.

A literacia, ou linguagem letrada, isto é, a forma de linguagem que adquirimos em virtude de termos inventado a escrita para representarmos através dela, de maneira permanente, a nossa linguagem oral, permite-nos fixar em "substância" o que, na realidade, é movimento, ação, transformação (outros substantivos a que a literacia terá dado corpo e existência), assim como de-contextualizar partes de frase e tratar palavras como objetos, permitindo uma reflexão analítica e comparativa, e a elaboração de um discurso, sobre a própria linguagem.

Tal como todas as ciências nasceram da forma permanente que a escrita deu aos produtos das nossas capacidades de imaginação, interrogação, analogia, predição, inferência, abstração, também transformamos em entidades o que são qualidades comuns a certos processos, e assim alguns destes tornaram-se "biologia", e outros "cultura".

Como desenvolvemos a capacidade de categorização (que deve ser anterior à escrita, mas se consolidou com a literacia), temos tendência não só a criar categorias, mas também a criar oposições entre categorias. Há, assim, uma tendência muito forte, pelo menos no comum das pessoas medianamente letradas, a opor biologia e cultura, através da oposição "natureza" vs. "cultura". O raciocínio subjacente é muito simples: Os fenômenos biológicos são os que se referem especificamente à vida; a vida é natural, anterior a nós, e a nossa vida acolhemo-la tal como ela é (depende da nossa genética); enquanto a cultura resulta das formas que tomam as relações sociais entre os seres humanos e do que eles produzem.

A oposição entre uma história natural e uma história cultural é uma falácia que deve ser corrigida, tal como muitas outras oposições conceituais para que a literacia contribuiu, mas que a atitude crítica em literacia e para com a própria literacia pode e deve ajudar a desconstruir. Os seres humanos vivem, naturalmente, em sociedade, ou seja, viver em sociedade faz parte da sua natureza. As interações sociais nas comunidades humanas criam cultura, mais exatamente culturas. A diversidade cultural faz, portanto, parte da nossa natureza, da nossa biologia.

Reciprocamente, a nossa biologia transformase em função da nossa atividade culturalmente determinada. Temos tendência a considerar muito respeitosamente a genética como uma divindade que nos governa e contra a qual nada podemos. Como se 
dependêssemos das suas mutações aleatórias (há quem acredite que tivemos a sorte de receber a linguagem através de uma ou algumas dessas mutações). Talvez essa teoria reflita ainda a antiga crença de sujeição a forças superiores contra as quais nada podemos porque são imprevisíveis.

A mudança nos seres vivos é vista como uma evolução que depende dos sobressaltos ocasionais na sua genética. Na realidade, os seres humanos agem sobre a sua própria genética (ou a genética de outros seres vivos), mesmo não o sabendo, ou sabendo-o como já acontece através de manipulações laboratoriais. A literacia acompanha essas manipulações deixando nelas a marca irônica do alfabeto: $A, T, C, G$.

Quando, no passado, certas comunidades humanas invadiram o território de outras, e os homens invasores mataram os que lá encontraram e fornicaram com as suas mulheres, eles mudaram a genética das gerações ulteriores. Mais: a cada geração, os genes podem ser utilizados pelas células de maneira adaptativa, sem modificação do ADN (é a chamada epigenética), conduzindo a modificações biológicas e comportamentais.

As comunidades humanas, através das suas culturas, transformam a vida, invadem o espaço extraterrestre. Enquanto isso acontece, enquanto aqueles letrados que mais diretamente intervêm nessas mudanças e aqueles outros que, por ganância, põem em perigo a ecologia da Terra, a sobrevivência das suas espécies e dos próprios seres humanos, condena-se dois terços destes a não poderem usufruir das capacidades de literacia crítica que Ihes permitiria assestar um murro na mesa, recusar serem explorados, mantidos na ignorância e afastados do que a humanidade, toda ela, deveria tornar-se: uma verdadeira democracia política e social, unida e coerente, na base dos valores de liberdade e de respeito da igualdade de direitos.

\section{Processos evolutivos e emergentes}

O conceito letrado de evolução ("conceito letrado" é uma expressão um tanto pleonástica porque todos os conceitos, porém não todos os significados ou sentidos, são letrados) refere-se a mudanças num ser, relação etc., que são essencialmente programadas, inerentes à sua temporalidade.

Evolução é a mudança, através das gerações, de características hereditárias dos organismos, características que resultam de trocas com o meio, e essas trocas, para o organismo, são fonte de experiência. A linguagem, ninguém duvida, depende da biologia humana. De uma forma de mudança, a mutação genética que se revela adaptativa, e de um tipo particular de experiência, a comunicação entre os indivíduos, que é uma característica biológica, sem a qual a linguagem não se desenvolve.

Mas a linguagem também muda por emergência. Emergência é a resultante de encontros. Enquanto as trocas com o meio, na origem da evolução, são obrigatórias e previsíveis, os encontros são dispensáveis, aleatórios, tornados frequentes pela diversificação, e conduzem à combinação de elementos, a interações que mudam as coisas e os seres, e, portanto, também as suas propriedades.

O exemplo mais comum de emergência provém da química: é a água, que resulta de uma combinação proporcionada de oxigênio e hidrogênio. Mas também é descrita nas outras ciências: na física (por exemplo, o choque de meteoritos na Terra, que talvez tivesse provocado a extinção dos dinossauros), na biologia, na sociologia, na política (onde alguns processos emergentes, como golpes militares e movimentos provocados por manipulações da opinião popular, são muito desagradáveis).

Os processos emergentes também ocorrem frequentemente na psicologia: por exemplo, a aquisição da literacia conduz a um aumento importante da capacidade da memória auditiva. E na linguística: por exemplo, a presença de línguas nativas no português brasileiro não resulta de um processo evolutivo, mas sim emergente, pois não teria existido se o Brasil tivesse sido descoberto e colonizado por outro país.

À primeira vista, os decursos temporais dos dois processos são diferentes. A evolução biológica é 
lenta, mas não tão lenta como se julgava, porque, como disse atrás, se sabe hoje que, para além da genética, há a epigenética, responsável por mudanças eventualmente reversíveis. $\mathrm{E}$ os processos emergentes, esses, resultando de encontros muitas vezes imprevisíveis, podem ser desencadeados rapidamente.

Consideremos mais de perto as diferenças nas mudanças da linguagem em função da escala temporal. Geralmente fala-se de evolução da linguagem ao longo da história do gênero Homo. A linguagem já estaria presente na espécie Erectus, mas ainda não com muitas das características, do ponto de vista anatômico e consequentemente articulatório, que se observam ou se inferem a partir dos restos dos Sapiens nossos ascendentes de há muitos milhares de anos.

Em contrapartida, fala-se de desenvolvimento, e não de evolução, da linguagem ao longo do crescimento das crianças Sapiens nossas contemporâneas. A noção de desenvolvimento pressupõe que a mudança, embora programada, só ocorre mediante certas exigências em termos de contexto e influências exteriores. A linguagem na criança não se desenvolve sem interações repetidas com adultos e/ou outras crianças e exposição à sua linguagem falada ou gestual.

Esta distinção entre evolução e desenvolvimento é aceitável e procedente, mas não deve conduzir à ideia de que a evolução, contrariamente ao desenvolvimento, seja um processo em "vaso fechado". Nada se faz sem trocas com o meio ambiente, ou pelo menos influências dele. Sem elas, dependendo do seu grau de necessidade e pertinência, não há evolução, mas involução, e não há desenvolvimento, mas empobrecimento, contração.

A linguagem no indivíduo não evolui, desenvolve-se. Ela não é exclusiva do ser humano. Outras espécies animais possuem alguma forma de linguagem. Porém, a fala, enquanto forma de linguagem, essa, é específica ao ser humano. O fato de algumas espécies de aves poderem imitar a nossa fala não anula essa especificidade, porque nelas a fala não é linguagem, é só cópia. E a escrita também é específica ao ser humano. Obviamente, os seres humanos podem criar seres artificiais capazes de linguagem oral e escrita.

No caso da linguagem, o processo de desenvolvimento é muito diferente conforme se trata da aquisição da linguagem oral (ou de sinais) ou da linguagem escrita: ocorre em idades diferentes e implica um tipo de relação muito diferente com os elementos do meio que o permitem. A primeira está sujeita a um período sensível, associado ao desenvolvimento do cérebro na infância, enquanto a segunda depende da aquisição da primeira (não necessariamente da fala, porque na ausência desta a sua percepção pode ser suficiente), mas pode ser adquirida, em princípio, em qualquer idade. Note-se que o termo "aquisição" é neutro, adapta-se a processos diferentes, sujeitos a condições diferentes.

As diferentes condições de aquisição da linguagem oral e escrita, isto é, na pequena infância (de fato desde o nascimento e até antes) para a primeira, e a necessidade de ensino metódico para a segunda, têm consequências que são da maior importância para a questão da riqueza e da pobreza das linguagens, e portanto também da riqueza e da pobreza em bens materiais e nas condições de vida.

Como vimos atrás, há uma relação muito forte entre a riqueza/pobreza material e em condições de vida (estas incluindo os fatores saúde, alimentação, habitação, cultura, estimulações positivas, exposição à linguagem letrada, etc.). Isto faz com que essa riqueza/pobreza determine em grande medida e com elevada probabilidade, o desenvolvimento, em qualidade, organização, extensão e profundidade, da linguagem oral, e até a precocidade, ou não, da aquisição de uma forma de literacia chamada emergente (se sim, ainda não sabe ler e escrever, ou muito pouco, mas já mergulhou dentro e já sabe o que é e que é coisa boa).

Oficialmente, a aprendizagem da leitura e da escrita começa para todos no $1^{\circ}$ ano da escola primária. Não é verdade. O pelotão, logo de entrada, estira-se pela estrada, os da frente respiram o êxito e a felicidade inerente, outros seguem assim-assim, 
mais atrás não se sofre dos músculos, é a dor de cérebro, a confusão nos ouvidos e a língua entaramelada. Nessa primeira etapa tudo parece estar decidido. O que poderia não ser uma corrida, antes uma cooperação entre todos e um sucesso coletivo, tornou-se a primeira exibição, para essas crianças, do que é a sociedade dos ricos e dos pobres. Má educação para todos eles! Os vencedores não socorrem os vencidos. $E$ as professoras, os professores, interrogam-se sabendo que não têm remédio para aquilo.

\section{Universalizar a literacia}

Ponhamos termo à lamentação! O retrato acima esquissado de uma sociedade clivada em ricos e pobres em literacia não corresponde de maneira nenhuma a uma inevitabilidade evolutiva ou de desenvolvimento. Muitas são as possibilidades de movimentos e encontros com efeitos emergentes que permitam tomar outra direção, a da universalização de altos níveis de literacia.

São vários os caminhos. Começarei por identificar dois que devem estar abertos a todos os que querem empreendê-los: os de combate político e de confrontação ideológica; e terminarei com o da educação em geral, que inclui a formação à literacia. O combate político por uma sociedade justa para com todos e cada um, de maneira geral e no que respeita à literacia em particular, trava-se em muitas frentes. Ele tem lugar no quadro das instituições políticas e cívicas, estas últimas incluindo as comunitárias, associativas e cooperativas, mas também fora de quaisquer quadros, porque a manifestação política deve poder ser livre, individual como coletiva, e intervir em qualquer momento.

A política e o exercício de funções políticas dizem respeito a todos. Ora, atualmente, estas funções são exercidas em 70 a $90 \%$ dos casos por diplomados das Universidades (BOVENS; WILLE, 2017), isto é, a direção política do povo é escandalosamente sonegada a este. Assim como, em cada país, as mulheres e os homens deveriam ter igual representação nos órgãos políticos, e, proporcionalmente, as diferentes classes de idade e de rendimento, as várias etnias e cores de pele, os estrangeiros e os habitantes nacionais, também a representação dos diferentes graus de literacia deveria ser proporcional enquanto não estiverem generalizados os seus mais altos níveis.

A confrontação ideológica assenta na livre expressão de ideias sobre o que é justo ou não, socialmente e individualmente. A ideologia é o sistema de ideias que cada um(a) tem sobre o que é ou deve ser a realidade em geral, o que inclui concepções filosóficas, metafísicas, epistemológicas, científicas, morais, éticas, axiológicas, sociais, políticas, estéticas... Como os seres humanos interagem uns com os outros e fazem, ou procuram fazer, opções comportamentais e relacionais que quase sempre afetam os outros, a confrontação ideológica é intensa e influenciada pelos níveis e tipos de literacia dos intervenientes.

A confrontação ideológica está presente no combate político: em princípio orientando-o; porém, os objetivos do combate político podem perturbar e confundir a confrontação ideológica. Isso faz com que o tipo de opções ideológicas e políticas e o grau de consistência entre elas sejam fortemente influenciados pelo nível elevado ou baixo de literacia crítica (e autocrítica). Uma consequência óbvia dessa influência da literacia na relação entre ideologia e política é a necessidade de integrar o tipo de exame crítico que a literacia torna mais preciso e profundo à compreensão dessa relação, ao longo de todo o processo educativo.

O lema "Escola sem partido (ou sem ideologia)", que o atual governo populista de extremadireita do Brasil procura impor, tem de ser denunciado e rejeitado totalmente porque ele serve apenas o projeto de suprimir o exame crítico que a literacia permite e de manter as velhas ideologias acríticas baseadas em preceitos retrógrados e obscurantistas que sustentam o poder das classes privilegiadas.

O ensino da literacia não é só o ensino das habilidades de ler e escrever. Estas habilidades têm uma função, que é a de permitir que a linguagem letrada tenha um impacto considerável no 
pensamento e na racionalidade. O pensamento livre e crítico é necessário para se alcançar um pensamento justo, preciso e produtivo.

\section{Explicando como a literacia emergiu, a palavra e os seus sentidos}

A literacia é, basicamente, linguagem letrada e conhecimento letrado. Ela emergiu do encontro de capacidades cognitivas e da linguagem oral suscitado por uma necessidade, a de fixar a informação e de libertar a comunicação da presença física dos interlocutores. A literacia não é apenas alfabética. A invenção do alfabeto ocorreu alguns milênios depois da emergência das primeiras formas de escrita. A utilização pelos gregos de certos caracteres consonânticos dos fenícios para representarem vogais terá sido intencional, mas não se fez em plena consciência das suas implicações.

Outros sistemas utilizados atualmente são tão eficientes como a escrita alfabética. A ainda alegada superioridade do alfabeto resulta sobretudo de este sistema ter servido, na Grécia clássica, ao pensamento filosófico e lógico (este fundado precisamente nos caracteres alfabéticos); de, muito mais tarde, ter alimentado, por via do alfabeto romano, o grande desenvolvimento da ciência e da cultura letrada a partir do Renascimento na Europa; e de, nos últimos três séculos, ser o sistema utilizado nos dois países que foram, econômica, tecnológica e militarmente, os mais poderosos, sucessivamente a Grã-Bretanha e os Estados Unidos da América.

Colonizadores e imperialistas, esses países impuseram ao mundo a língua inglesa, que sempre adotara o alfabeto romano. A ciência contemporânea, ainda por via do inglês, produziu uma outra forma de literacia, a informática, que tem servido ao desenvolvimento extremamente rápido da inteligência artificial. Esta utiliza em parte a escrita digital, símbolos numéricos, 1 (o "pau" vertical era o único símbolo dos sistemas unários) e 0 (zero, contração italiana - renascentista - do latim medieval zephiro, transcrição da palavra árabe que designa o vazio).
O termo literacia não é reconhecido no Brasil, embora já seja muito utilizado em Portugal. No Brasil, e só no Brasil, utiliza-se a palavra "letramento", que é uma palavra antiga, caída em desuso e retomada há pouco menos de 40 anos. "Letramento" não serve para designar o conceito expresso pela palavra literacia, porque esta designa uma capacidade, enquanto letramento designa um processo, uma ação, neste caso a aquisição das letras.

"Letramento" é também apresentado no Brasil como designando uma prática social, o que é pouco específico porque as práticas sociais são inúmeras, e é reducionista porque ler e escrever podem ser também atividades íntimas. De qualquer modo, como o inglês é a língua da ciência, da comunicação social e do poder político e econômico, a palavra letramento não tem a menor chance relativamente à literacia.

Literacia, tal como letrado, literatus, o sujeito de literacia - note-se que há muitos letrados que não são alfabetizados -, são palavras derivadas das letras do alfabeto latino. Se tivermos em conta a sua etimologia, literacia é uma palavra já influenciada pelos caracteres do alfabeto (as letras), mas não se dispõe de melhor alternativa. Inevitavelmente, ela herda de uma história que não é possível refazer.

A primeira ocorrência da palavra inglesa literacy, de origem latina, parece ser de 1883. Foi pouco utilizada na primeira metade do século $X X$, mas difundiu-se muito na segunda metade, e agora é utilizada em todas as publicações internacionais. $\mathrm{Na}$ língua francesa, por razões geopolíticas óbvias, foi no Québec que littératie começou a ser utilizada, depois seguiu-se a Suíça e a Bélgica, e nos últimos dois ou três anos a França, que durante muito tempo a recusara nos textos oficiais (embora ela já fosse utilizada por linguistas), acabou por submeter-se.

Como já referi acima, mas desenvolvo agora, entendo que o conceito de literacia, que inclui a linguagem letrada, tem 3 sentidos: O primeiro é a capacidade de ler e escrever palavras de maneira hábil, isto é, tendo acesso automático, na leitura, às palavras orais correspondentes e, na escrita, às suas representações ortográficas. 
O segundo é a capacidade (cognitiva, estética, intencional e participativa) de utilizar essas habilidades para adquirir conhecimentos, examinar criticamente os conhecimentos existentes, criar outros conhecimentos e transmiti-los, sentir e transmitir beleza, emoções, valores, e, indo mais além, desenvolver a linguagem, mas também capacidades cognitivas como a percepção, a atenção, a memória, o raciocínio, e utilizar tudo isso para prazer pessoal e participação ativa na sociedade. Enfim, o terceiro sentido permite identificar domínios de literacia, ou seja, a competência em uma determinada área, que pode ser literacia científica, literária, informática ou digital, de saúde, da mídia, financeira etc.

\section{As habilidades básicas do letrado}

Quais são as habilidades básicas do letrado? Elas consistem, ao ler, em identificar as palavras escritas e, ao escrever, em acessar as suas representações ortográficas, de maneira automática, isto é, os processos utilizados, embora extremamente rápidos, são complexos. Estes processos, dos quais não temos consciência no momento, têm sido postos em evidência pela psicolinguística cognitiva da leitura e da escrita.

A sua aprendizagem passa por fases características. A automatização da leitura e da escrita no caso do sistema alfabético começa pela decodificação e codificação intencionais e conscientes dos constituintes das palavras e isso fazse numa região posterior do hemisfério esquerdo do cérebro. De fato, a chamada Área da Forma Visual das Palavras (VWFA) constitui-se funcionalmente a partir de neurônios que inicialmente servem para o reconhecimento de faces e objetos, mas ainda sem função específica definida (cf. DEHAENE; COHEN; MORAIS; KOLINSKY, 2015; KOLINSKY; MORAIS; COHEN; DEHAENE, 2018).

Ao longo da aprendizagem, há dois fenômenos muito interessantes. Por um lado, esses conjuntos de neurônios especializam-se no processamento das palavras escritas. E, por outro lado, essa VWFA vai estabelecer conexões cada vez mais integradas com várias áreas da linguagem, quer com o planum temporale, associado à fonologia, através do fascículo arqueado, no hemisfério esquerdo, quer com áreas do mesmo hemisfério que intervêm na compreensão e na produção da linguagem. Em contrapartida, a conectividade da VWFA diminui tanto com as outras áreas de reconhecimento visual (de outras formas) como com as outras áreas auditivas não linguísticas.

Assim, a leitura e a escrita, de início um fenômeno essencialmente visual e associado à fonologia, passam a fazer parte do sistema muito mais complexo da linguagem, e por isso a literacia merece bem o nome de linguagem letrada. A nossa linguagem é, sim, uma linguagem letrada. O "nós" subentendido por "nossa linguagem" refere-se a mim e a todas e todos (em princípio, leitoras e leitores habituais desta revista linguística) que me leem sem dificuldade, compreendendo o que escrevi. "Nós" somos letrados, "ricos" em leitura e escrita. Obviamente, a grande maioria da população brasileira não cabe neste "nós". Como já disse atrás, nós não somos todos necessariamente ricos em bens materiais, e os que não conseguem compreender este texto não são necessariamente pobres em literacia. Já os que o compreenderam e estiverem completamente em desacordo comigo partilham a nossa "riqueza" em literacia e convido-os para debate.

Muitos de entre "nós", letrados, não têm a noção ou fingem serem "ricos" no sentido de privilegiados. Numa publicação baseada em dados da CIA (ROSER; ORTIZ-OSPINA, 2016), a literacia era apresentada como "mais desenvolvida do que nunca", porque teria aumentado de $12 \%$ da população mundial em 1820 até mais do que $80 \%$ atualmente, com a consequência de "melhorias gigantescas em todo o mundo e uma forte redução das desigualdades entre os países e neles mesmos, e, nos USA, uma quase supressão das diferenças raciais." Pangloss, 0 preceptor de Candide e personagem de Voltaire, já dizia que "neste melhor dos mundos possíveis (...) tudo está pelo melhor'. Que ilusão! Ou que embuste! 
Segundo a ONU, para se verificar se alguém é letrado ou iletrado, tem-se recorrido às declarações (em resposta a "sabe ler e escrever?") feitas em 76 países; aos inquéritos a domicílio feitos em 53; e a testes em 23. Deve dizer-se que, entre os séculos XVI e XVIII, nos países europeus, a prova de ser letrado, que servia para as estatísticas, era a assinatura nos contratos de casamento. De qualquer modo, é difícil entender como a ONU terá procedido para concluir que, em 2015, os iletrados no mundo (segundo o critério "incapacidade de ler e escrever um texto simples típico da sua vida") eram $15 \%$ acima dos 14 anos, e $9 \%$ entre 15 e 25 anos, sendo as mulheres iletradas duas vezes o número dos homens iletrados.

Há também, regularmente, o inquérito da OCDE "Skills Matter" (2016b), relativo aos adultos entre 25 e 65 anos de países quase todos desenvolvidos (as médias são calculadas sobre os países, portanto ignorando as diferenças de população entre os países). Note-se que aqui, tal como no PISA referido atrás, não foram aplicados testes de escrita nem da habilidade de leitura de palavras. Só 35\% foram capazes de derivar significado a partir de grandes passagens de texto, e só $10,7 \%$ foram capazes de avaliar discurso. Assim, nestes países desenvolvidos, em que se incluem o Japão (296, muito acima da média, que é de 268), a Rússia (275), a Grã-Bretanha (273), a Alemanha e os USA (270) e a França com apenas 262, só uma pequena percentagem de cidadãos está em condições de participar na vida política e de utilizar o seu direito de voto em conhecimento de causa.

Creio que podemos responder agora à questão que coloquei há pouco: se, na expressão "a nossa linguagem", linguagem é aquilo que queremos que seja, linguagem letrada, e "nós" é o conjunto daqueles que a utilizam realmente com proficiência, então este "nós" é uma elite e a democracia é uma ficção (ou uma mentira). Contrariamente aos dados da CIA, estes resultados, os do Skills Matter e os do PISA, não mostram que a sociedade em que vivemos é letrada. Nem no Brasil nem sequer nos países da OCDE, se entendermos que a literacia deve incluir capacidade de apreciação crítica. A sociedade é todo o mundo, não podemos excluir ninguém.

Uma maioria de não-letrados é dirigida por uma minoria de letrados: é o que dois autores holandeses, Bovens e Wille, chamaram de "Diploma Democracy", apoiando-se nas estatísticas. Atualmente, perto de $90 \%$ dos indivíduos que compõem os governos e os parlamentos dos principais países europeus têm diploma universitário, incluindo doutorado. Nós fazemos parte daqueles que os elegem.

\section{A emergência dos processos mentais e específicos à literacia}

A literacia, além de linguagem letrada, é também pensamento letrado. A literacia foi e continua sendo a obra de seres humanos engenhosos que viviam e agora vivem em culturas que a favorecem. $E$, como já referi, ela não evoluiu, no sentido biológico, ela emergiu. $O$ seu resultado (output) é irredutível aos seus componentes. A emergência é uma gestação, mas neste caso o nenê é a mente letrada. Ninguém melhor do que Diderot, no século XVIII, exprimiu a emergência da mente letrada (embora a ideia tivesse passado em várias outras cabeças daquele tempo e embora Diderot ainda não utilizasse a palavra emergência, mas claramente tinha o conceito). Ele utilizou o instrumento da literacia (o livro) e uma das suas duas atividades (a leitura) para se referir à relação entre o cérebro e a mente: "o cérebro é um livro que se lê a si mesmo".

No Sonho de d'Alembert, a personagem de Diderot pergunta à personagem D'Alembert, "o que é a memória, de onde ela nasce?" e a personagem d'Alembert responde-lhe: "de uma certa organização que cresce (...) é uma qualidade corporal, uma qualidade orgânica". E noutra obra, póstuma (Éléments de Physiologie): "Para explicar o mecanismo da memória é preciso olhar para a substância mole do cérebro como uma massa de uma cera sensível e viva, mas suscetível de todas as espécies de formas. (...) Eis o livro; mas onde está o 
leitor? É o próprio livro. Porque o livro sente, vive, fala (...) e como se lê ele a si próprio? Sentindo o que é".

Saindo um pouco, apenas um pouco, da metáfora: a mente é um cérebro que se sente. Diderot insistiu na "irredutível plasticidade cultural do cérebro" cerca de 250 anos antes de Stanislas Dehaene e os seus colaboradores terem mostrado que a ativação da VWFA é uma função linear do grau de literacia (DEHAENE; PEGADO et al., 2010). Diderot apresentou a "subjetividade (a mente) como um efeito, em vez de uma substância". Para Diderot, o cérebro é crucial, mas é plástico, inteiramente aberto à experiência.

A mente não existe, a mente é um conceito, e como palavra é um substantivo, suposto designar uma substância. Esse é o embuste da literacia. Faznos criar substâncias que não existem. A palavra, fomos nós, mais precisamente os letrados nossos antepassados, que a criaram, em muitas línguas. $\mathrm{E}$ que criaram também a ideia de mente para explicarem que uma entidade interna controla o nosso comportamento.

Somos letrados, por isso não podemos pensar e comunicar com os outros sem utilizar conceitos letrados. Só temos uma saída: procurarmos praticar constantemente uma literacia autocrítica. Digamos então que a atividade do nosso cérebro inclui diferentes tipos de processos, bioquímicos, fisiológicos, mentais, e que "mente" é apenas o conjunto dos processos mentais. Não precisamos de opor a atividade elétrica e atividade mental do cérebro, não há causalidade entre elas porque 0 cérebro vivo e a chamada mente não são entidades distintas. O que existe, portanto, são processos mentais, e estes processos são mais do que um efeito, porque eles agem sobre o nosso cérebro e sobre a realidade dos outros e do mundo, os quais por sua vez retroagem sobre os nossos processos mentais. A experiência é isso mesmo.

Quando colocamos uma criança na situação de aprender a ler e escrever, a "mente" da criança aprende e exatamente ao mesmo tempo o cérebro da criança muda, não antes nem depois. E o fato que provoca esta única mudança é a situação que a criança vive. A nós parece-nos ser uma realidade dupla, devido ao fato de termos óculos letrados permanentemente diante dos nossos olhos. E como toda a nossa ciência é letrada, sofremos constantemente desta nossa diplopia epistêmica.

Vejamos, rapidamente, alguns exemplos de como a literacia nos muda. Eles mostrarão por que é que Régine Kolinsky e eu próprio propusemos a seguinte definição de literacia: "tudo o que no indivíduo ou na cultura à qual o indivíduo pertence, resulta, resultou ou resultará direta ou indiretamente do desenvolvimento e do uso da tecnologia da escrita" (KOLINSKY; MORAIS, 2018, p. 322) ${ }^{3}$.

\section{Exemplos de impacto da literatura nas funções cognitivas}

\subsection{Na percepção visual}

Nascemos com uma capacidade, a de identificarmos um objeto orientado à direita ou à esquerda como sendo o mesmo objeto. De fato, um tigre orientado à direita ou à esquerda é sempre um tigre e é melhor fugir dele. Mas para aprendermos o nosso alfabeto latino e a grande maioria dos sistemas escritos, isso é um problema (já que no nosso alfabeto $<$ b $>$ é a imagem em espelho de $<\mathrm{d}\rangle$, e $<\mathrm{q}>$ de $<\mathrm{p}>$ ). Assim, temos de aprender a discriminar as formas em espelho, a habilidade chamada enantiomorfia. Kolinsky et al. (2011) mostraram que os iletrados têm grande dificuldade para discriminar as imagens em espelho, e que os letrados que aprenderam a discriminar esses pares de letras tiveram de "desaprender" a invariância de orientação.

Outro efeito interessante da literacia é o aumento da ativação da região cerebral V1 no córtex visual primário em resposta a traços horizontais de padrões visuais, mas não a traços verticais. Isso pode resultar do nosso enorme treino perceptivo de leitura de textos em linhas horizontais. Se esta hipótese é

\footnotetext{
${ }^{3}$ Literacy is all that in the individual or in culture to which the individual belongs, results, has resulted, or will result directly or indirectly from the development and use of the writing technology (KOLINSKY; MORAIS. The worries of wearing literate glasses, in L'Année Psychologique / Topics in Cognitive Science, 2018, p. 322).
} 
correta, deveríamos observar o efeito oposto na ativação de V1 em leitores de línguas escritas em colunas verticais.

\subsection{Na percepção da fala}

Suponhamos que temos de responder manualmente o mais depressa possível, mas sem errar, se o que ouvimos é uma palavra ou uma nãopalavra. Essa tarefa tem o nome de decisão lexical auditiva. Em 1998, dois pesquisadores franceses, J. Ziegler e L. Ferrand, mostraram que o tempo de reação às palavras, mas não às não-palavras, é maior se houver inconsistências ortográficas do que se não houver. Em português isso não é muito frequente, mas há casos de inconsistência, por exemplo, maçã e massa, ora e hora, etc. Em francês há muito mais.

Mais recentemente, Pattamadilok et al. (2014) mostraram que esse efeito não depende da atenção. Expusemos os ouvintes a sequências muito aborrecidas de sons como tri-tri-tri etc., sem lhes pedirmos nenhuma tarefa, enquanto viam um filme. Em certos momentos da sequência havia / kri/ ou /pri/ em vez de /tri/. Todos esses sons são palavras em francês, mas /pri/ pode escrever-se "prix" ou "prit" ou "pris" ou "prie", portanto de pelo menos de 4 maneiras diferentes. A sua apresentação ocasional, mas não a de $/ \mathrm{kri} /$, provocou um efeito muito precoce num componente (pouco mais de 100 milésimos de segundo a partir do início da palavra) chamada mismatch negativity, que reflete a incerteza da identificação, o que quer dizer que as representações ortográficas correspondentes são ativadas quando ouvimos palavras mesmo sem lhes prestarmos atenção. Somos letrados e nunca conseguimos deixar de sê-lo. Neste caso, não são óculos que não conseguimos tirar, são os nossos auscultadores letrados, o nosso tradutor automático em escrita.

Será isso desvantajoso? Não, é até muito vantajoso, porque implica que temos disponíveis, sem sequer termos de prestar atenção, duas fontes de informação (acústica e ortográfica) para interpretarmos a fala, a linguagem oral. Obviamente, os iletrados e provavelmente os maus letrados não têm essa contribuição da literacia à percepção da fala.

8.3 No conhecimento consciente da linguagem (metalinguístico)

São muitas as manifestações da influência da literacia no nosso conhecimento da linguagem. Vejamos apenas dois exemplos, um que é característico da escrita alfabética, enquanto o outro se observa também em outras escritas. O primeiro revela que os iletrados não têm consciência dos segmentos ou unidades da fala que correspondem aos fonemas. Essa descoberta foi publicada há 40 anos (MORAIS et al. 1979), tendo depois sido confirmada várias vezes. O artigo em questão já foi citado quase 1600 vezes na literatura. No entanto, antes de ser publicado foi recusado pela revista Science. A razão da recusa foi que um dos revisores, certamente um ótimo cientista, não acreditou no resultado, isto porque já tinha sido demonstrado que mesmo nenés discriminam entre /ba//da//ga/. Ele estava, como muitos outros, confundindo a representação consciente dos fonemas e a capacidade de discriminação fonética. A segunda pode fazer-se sem a primeira.

Deve dizer-se que se nós descobrimos o fato, a demonstração de que ele se deve sem qualquer dúvida à literacia alfabética foi feita por Charles Read e seus colegas chineses 7 anos mais tarde. Este artigo (READ et al., 1986) tem agora quase 1000 citações). Esta insistência nas citações tem por objetivo salientar que esse fenômeno (o fato de a consciência dos fonemas ser uma consequência da aprendizagem da escrita alfabética), tendo surpreendido muita gente letrada e até especialistas da percepção da fala, é autêntico e importante. É-o, por um lado, para a compreensão dos diferentes níveis de processamento e de representação da fala, e, por outro, para a compreensão da necessidade de provocar a tomada de consciência dos fonemas no início da aprendizagem da leitura e da escrita quando esta codifica as unidades fonêmicas da língua. 
Provavelmente, nunca teríamos descoberto a "unidade" fonema se a escrita alfabética não tivesse sido inventada. E esta invenção terá suscitado, nos que aprendem essa escrita, uma intuição ilusória, a de que nós "ouvimos fonemas". A verdadeira realidade do fonema só foi posta em evidência, quase três séculos depois da invenção do alfabeto, por Alvin Liberman e os seus colegas dos Laboratórios Haskins (LIBERMAN et al., 1967), e foram esses trabalhos que estiveram na origem das descobertas de Morais et al. (1979) e de Read et al. (1986). Estes, na realidade, não evidenciaram um fenômeno real, apenas dissiparam uma ilusão. Mas essa retificação, para além da questão teórica, contribuiu para confirmar a importância de configurar corretamente o método fônico, que na realidade, por se fundar na compreensão e na aprendizagem das correspondências grafema-fonema e fonema-grafema (para além das muitas irregularidades permitidas) poderia ter sido apelidado de "fonêmico-grafêmico".

O segundo exemplo de influência da escrita diz respeito à noção de palavra. Em 1987, Kolinsky et al. mostraram que os iletrados não têm a mesma noção de palavra que nós, letrados. Pedimos-lhes que dissessem uma palavra curta e uma palavra longa: entre os iletrados só houve $16 \%$ de respostas corretas (ex-iletrados: 75\%); 30\% dos iletrados disseram frases, por ex., "eu gostaria de ser capaz de ler" vs. apenas "eu gostaria" (ex-iletrados: 5\%); 15\% dos iletrados utilizaram características do ato de fala: por ex. Margarida, primeiro muito forte e num tempo normal, depois murmurado e mais rápido (exiletrados: $0 \%$ ); $25 \%$ dos iletrados responderam com palavras de objetos pequenos/grandes, e.g., nogueira; "porque é uma árvore grande") vs. galinha; ou em referência à importância emocional do objeto: 14\% (ex-iletrados : 0\%).

Esse desconhecimento da unidade palavra foi confirmada com outras tarefas. Assim, Cary (1988) observou que, convidados a segmentar uma frase simples em palavras, por exemplo, "O ônibus está parado perto da casa", os iletrados, mas não os letrados obviamente, dividem geralmente em três constituintes (o ônibus) (está parado) (perto da casa)
- NV-VP-PP, resultado de uma intuição gramatical e quando se pede que dividam mais cada um desses constituintes, eles não dividem em palavras mas em sílabas. Os iletrados só produziram 4\% de segmentações em palavras, enquanto os ex-iletrados produziram $48 \%$, e os letrados precoces $86 \%$.

A nossa escrita coloca espaços entre as palavras, e isso até é relativamente recente. Porém, o que é exatamente uma palavra não é claro. No português de Portugal, pode dizer-se ou escrever correntemente "dir-to-ei". Não diria que o conjunto é uma palavra, e de fato nenhuma das três partes é palavra. Uma palavra (direi) foi desmembrada por um clítico que indica que (eu) disse alguma coisa a alguém, a ti.

De tudo o que precede se infere que a escrita influencia profundamente a nossa análise consciente da língua oral. A nossa linguística é uma linguística letrada, e, mais perturbador, não há linguística que não seja letrada. Ou mais exatamente: as intuições dos iletrados sobre a linguagem são muito diferentes das nossas.

\subsection{Na memória verbal imediata}

Apenas uma observação breve, seguida de um comentário de maior importância. Vários trabalhos mostram que o número de itens verbais (por exemplo, palavras ou nomes de algarismos) que os iletrados são capazes de repetir imediatamente em sequência totalmente correta é metade ou pouco mais da metade do desempenho dos letrados (7 itens vs. 4.1, em média) (cf., por exemplo, Reis et al., 2003).

Por que razão ou razões uma tão grande diferença? Porque o iletrado só tem acesso à persistência de uma corrente de representações auditivas que apresentam algumas similitudes entre elas, o que contribui para confundir a sua sequência temporal e provoca erros quer de identidade quer de ordem. Ao passo que o letrado, para além dessas representações auditivas, dispõe, inconscientemente, de representações ortográficas, portanto de natureza visual, que são ativadas automaticamente graças ao seu conhecimento da ortografia das palavras e 
pseudopalavras, e, também, de representações fonológicas de um maior grau de definição e precisão (por exemplo, fonemas e outras unidades subsilábicas como ataques complexos, br-, cl-) que aquelas que o iletrado pode formar (da ordem da sílaba ou mesmo da globalidade do item).

Esse efeito, à primeira vista, não parece extraordinário. Porém, as suas implicações são enormes, porque a memória verbal a curto prazo é utilizada em quase todas as atividades cognitivas que envolvem a linguagem, e essas são muitas porque o próprio pensamento e a forma de pensamento chamada raciocínio recorrem à linguagem. Assim, o iletrado é como um computador primitivo, dos que já não se vendem, dos que ninguém quer, porque 0 letrado pode processar muito mais informação e mais complexa, envolvendo muito mais relações. Isto não quer dizer que o iletrado não pode raciocinar corretamente, apenas que, além de certas quantidades de informação, sobretudo quando os algoritmos são complexos, ele não pode competir com o letrado, embora possa ter razão e o letrado querer malevolamente confundi-lo.

\subsection{Na compreensão e na produção de frases}

São apresentadas abaixo três ilustrações de diferenças importantes entre letrados iletrados:

\section{a. Efeito da proximidade do agente e da sua ação:}

$\mathrm{Na}$ produção: Este caso foi-me contado por uma colega brasileira muitos anos atrás: os iletrados não diriam "o carro da Maria pifou", mas sim "A Maria o carro dela pifou". Mais tarde, os meus colegas franceses que trabalham em alfabetização de adultos deram-me vários exemplos desse tipo de construção como sendo extremamente corrente nos iletrados.

$\mathrm{Na}$ compreensão: Quando se apresenta a iletrados frases do tipo "If the boys watching the girls play ball, who plays ball?" ou "If the boys watch the girls play ball, who plays ball?", os iletrados respondem sempre "the girls", eles não têm em conta a forma do verbo "watch", e portanto das suas relações com os dois agentes possíveis. A sua compreensão é baseada na ordem e na contiguidade dos termos salientes: "girls play ball" aparece em ambas as frases (SCHOLES; WILLIS, 1987).

\section{b. Efeito da complexidade estrutural}

Muitas construções sintáticas letradas são opacas para as pessoas de baixo nível de literacia e algumas só são compreendidas pelos peritos. A título de exemplo, Dabrowska (1997) utilizou frases do Linguistic Inquiry (consideradas como inglês padrão, pelos linguistas), tais como (esta é uma das mais fáceis de compreender, mas confesso ter tido dificuldade):

(1) The mayor who Julie warned after learning the ex-prisoner wanted to interrogate managed to get away", then the participants had to answer a few questions (for example, "Who wanted to interrogate someone?")

Em média, sobre todas as frases, a percentagem de respostas corretas foi de quase $20 \%$ para o grupo menos letrado (pessoal da limpeza e da vigilância, com no máximo 10 anos de escola), cerca de $40 \%$ para os estudantes universitários do $1^{\circ}$ ano, de $60 \%$ para os que já tinham a graduação, e de $90 \%$ para os professores de línguas. Há, portanto, três espécies de linguagem: a linguagem real das pessoas escolarizadas, a linguagem letrada, como a dos estudantes de letras ou de psicologia; e a linguagem linguística. A linguagem letrada é mais sofisticada na escrita do que na fala, e em países em que a maioria da população é de baixo nível de literacia, como o Brasil, muitos letrados tendem a falar numa linguagem pouco ou nada letrada.

\section{c. A utilização dos clíticos}

Mary Kato (2005) mostrou que, historicamente, o pronome relativo ao sujeito - que é inútil quando as formas verbais são todas diferentes qualquer que seja o sujeito (falo, falas, fala, falamos, falais, falam) passou a estar presente na fala, e a concordância verbal enfraqueceu: tu brinca, eles entra... Segundo Corrêa (1999), a produção do clítico pelos estudantes universitários mantém-se na escrita $(80 \%)$, mas não na fala (apenas 14\%). E nos iletrados, o clítico ou é 
inexistente ("comprei o peixe sem examinar", em vez de "examiná-lo"), ou é substituído pelo pronome ("examinar ele").

d. Quando os letrados falam como os iletrados e os menos letrados o são muito mais

Aqui estão ilustrações da fala de políticos letrados (dos palavrões e dos nomes de pessoas só é indicada a primeira letra):

(2) - Cara, nós tamos vendo. Acabar com tudo esses crimes de falsidade ideológica, papapá, que é que na, na, na mão, texto pronto nãnã. $\mathrm{O}$. afirmando que tá com c... pra votar, nós tamo... O cara, cê tinha que mandar um, um, cê tem ajudado esses caras pra c..., tinha que mandar um recado pro R., alguém seu, tem que votar essa m... de qualquer maneira, assustar um pouco, eu tô assustando ele, entendeu? Se falar coisa sua aí... forte. Não que isso? Aí o povo vai pra rua e ele amarela.

(3) A função do governo é respeitar o dinheiro do contribuinte, ensinando para os jovens a leitura, escrita, e a fazer conta.

(4) Nos tamo num teatro.

(5) Não entendo um montão de coisa.

(6) No entanto, a perspectiva de implementar uma forte agenda anticorrupção e anticrime organizado, com respeito à Constituição, à lei e aos direitos, levaram-me a tomar esta decisão.

(7) - Eu tenho obsessão de desmascarar X, de desmascarar $Y$ e a sua turma, de desmascarar aqueles que me condenaram, que eu ficarei preso cem anos, mas eu não trocarei a minha dignidade pela minha liberdade (...) Então como eu quero viver até os 100 anos (...), eu vou trabalhar muito para provar a minha inocência e a farsa que foi montada.

Este último é reconhecível e merece reconhecimento. Ilustra frases de alguém que só tem diploma de ofício manual (torneiro mecânico). É Lula! Lula, que como Lincoln, lutou - e continua a lutar para combater a escravidão social e para caminhar no sentido da democracia. Lula, que abriu as portas das Universidades federais a muitos mais negros e pardos do que antes dele. Lula injustamente preso, por conjuração de uma boa parte das forças reacionárias do Brasil, incluindo de letrados hipócritas e pretenciosos.

Como escreveu o Papa Francisco em uma carta a Lula, publicada na imprensa em 5 de junho de 2019, o lawfare, "a prática que resulta de uma atividade judicial imprópria em combinação com operações midiáticas paralelas" tem por consequência "colocar a democracia dos países em sério risco" e "incentivar a violação sistemática dos direitos sociais".

Lula livre! Língua livre! Liberdade!

\subsection{Na organização do espaço tempo}

A literacia também influencia a orientação espaço-temporal do discurso. Nos letrados, a orientação espaço-temporal das imagens é influenciada pela orientação da escrita: o alinhamento de ovo à galinha passando por pinto é feita da direita para a esquerda pelos que falam hebreu, da esquerda para a direita pelos que falam inglês (FUHRMAN; BORODITSKY, 2010), e de cima para baixo pelos que falam taiwanês (BERGEN; CHAN LAU, 2012). Este efeito de orientação da escrita também é observado quando espanhóis e israelenses respondem com a mão direita ou esquerda a expressões que se referem ao passado ou ao futuro (OUELLET et al., 2010).

\subsection{Na inteligência e no raciocínio}

Muitas pessoas acreditam, influenciadas por muitos autores, que a inteligência é uma capacidade natural, hereditária, dependente dos nossos genes, que nada tem a ver com a literacia e precede toda a educação. Acontece que o termo "inteligência" continua a ser usado por toda a gente, mas não existe definição científica precisa. Ela é medida como se tivéssemos um termômetro para a medir, mas diferentemente da temperatura, não sabemos o que é. Assim, a inteligência não é mais do que aquilo que se mede com testes supostamente capazes de medila e que calculam "quocientes de inteligência". 
Esses começaram por ser elaborados, no fim do século XIX, para estimar as capacidades de aprendizagem das crianças, quando a escola pública elementar começou a generalizar-se, na França. Pouco depois, esses mesmos testes foram adaptados nos Estados Unidos da América, para separar, entre os imigrantes que lá chegavam, aqueles que convinha aceitar (os inteligentes, obviamente) dos que, pelo contrário, convinha rejeitar (os imbecis).

Como a crença era de que a inteligência não só não depende da literacia, como também não depende do conhecimento de uma língua, os psicólogos norte-americanos da inteligência, que trabalharam para as Forças Armadas durante a Primeira Guerra Mundial, criaram testes com figuras (para identificar as partes que faltam ou sequências lógicas, contar cubos em desenhos, etc.) para os imigrantes que não percebiam inglês, nem escrito nem falado. Era a forma Beta dos testes Alfa, aplicados em grupo e baseados num princípio inovador, o da escolha múltipla, hoje largamente utilizado para tudo e todos, tanto nas empresas como nos estabelecimentos de ensino.

Entre os 360 mil homens testados, foram classificados na categoria $D$ (idade mental inferior a 11 anos) ou D- (entre 7 e 9 anos) 64,6\% dos imigrantes da Polônia, Itália e Rússia, mas apenas 10,1\% dos vindos da Dinamarca, Holanda e GrãBretanha (SWEENEY, 1922). Essas diferenças não foram interpretadas como podendo estar ligadas a diferenças de educação, mas como inatas e associadas a "raças", sem consideração pelo fato de todos serem exemplares da espécie Sapiens. O autor (pp. 600-612) comentou assim os resultados: "Os grupos na extremidade mais baixa da escala psicológica são [...] subnormais. [...] Este grupo (o primeiro) é completamente iletrado. [...] Eles pensam com a espinal medula e não com o cérebro. [...] são um arco reflexo, não um ser que raciocina.// $A$ educação só pode ser recebida por aqueles que têm inteligência para recebê-la. Não se cria inteligência. Nasce-se com ela. É inútil apelar à educação dos grupos mais baixos. O que é urgente é a educação dos grupos mais altos. [...] Se não fizermos isso, iremos fazê-los descer ao nível das raças Eslávica e Latina, com a sua iliteracia, ignorância e consequente degradação." O objetivo de toda esta montagem era político: mudar as leis da imigração.

Os testes Binet-Simon aplicados às crianças no $1^{\circ}$ ano de escolaridade conduziram a resultados semelhantes. O efeito do "stock racial" não era menos claro: as médias dos QI foram, para os de origem espanhola, 78; para os portugueses e italianos 84, enquanto os da Europa do norte atingiram 105 e os norte-americanos cujos ascendentes também provinham do norte da Europa 106 (YOUNG, 1922). Estaria, portanto, provada a origem inata das diferenças de inteligência, como se não contassem o conhecimento da língua, a familiaridade do contexto e o nível prévio de educação. Havia os genes da Europa do norte (os bons) e os da Europa do sul (os maus).

Para o biologista Stephen Jay Gould (1982), toda a testagem estava recheada de incompreensões. Os testes baseavam-se frequentemente em suposições sem fundamento. Por exemplo, verificar a capacidade de fazer analogias exigindo uma resposta correta a "Washington está para Adams como primeiro para segundo..." supõe que os candidatos à imigração vindos de outros países conhecem a história dos Estados Unidos. Isto para além de que um letrado nem se dá conta de que certas condições da testagem não são fáceis para um iletrado. No Beta, se as questões não eram formuladas verbalmente, os iletrados deviam utilizar uma caneta, o que só é fácil para quem está habituado a escrever.

A Lei de 1924 apoiou-se no slogan 'America must be kept American', tal como Trump e outros atualmente. A História repete-se. Ora, sem aquelas leis, os acontecimentos ulteriores não teriam sido trágicos como foram para milhões de pessoas. O passado lembra o futuro possível, segundo GOULD (1982, p. 352): "Ao longo dos anos 30, os refugiados judeus, antecipando o holocausto, procuraram emigrar, mas não foram admitidos. As quotas legais e a propaganda contínua, barraram-lhes a entrada (atingindo) seis milhões de Europeus do sul, do 
centro e de leste entre 1924 e a deflagração da Segunda Guerra Mundial. (...). Sabemos o que aconteceu a muitos que quiseram partir, mas não tinham para onde ir. Os caminhos da destruição são frequentemente indiretos, mas as ideias podem ser agentes tão certeiros como as espingardas e as bombas." É geralmente a isso que o racismo, o nacionalismo e a exclusão dos outros conduzem. E é por isso que é necessário desenvolver a literacia crítica, não para uma elite, que a utilizará para ela, mas para todos.

Abordando mais especificamente o raciocínio, é um fato histórico que a educação e a literacia nos permitiram desenvolver métodos e estratégias de raciocínio formalizado. Relembro que, sem a invenção da escrita, não se teriam desenvolvido a filosofia, a lógica e a ciência, nem sequer aparecido. A reflexão sobre o pensamento e o raciocínio é necessária para que estes não sejam apenas intuitivos. A literacia ajuda-nos a fazer essa reflexão, sobre si própria (metaliteracia) e sobre a cognição (metacognição), porque nos confronta com o que escrevemos e o que outros escreveram, no papel ou na tela, de maneira permanente, permitindo exames e retornos fora do tempo imediato.

Há quase 20 anos atrás, juntamente com Elias Mengarda, então doutorando de linguística, da UFSC, Régine Kolinsky e eu aplicámos um teste de raciocínio condicional, o conhecido teste de Wason, a iletrados, semiletrados e letrados (sendo os últimos universitários). Confrontados a 4 cartas dispostas na mesa, eles deviam indicar quais deveriam ser retornadas para se verificar a veracidade da seguinte afirmação: "Se uma carta tem um número par de um lado, então do outro lado ela é vermelha" (Se P, então Q). O lado visível mostrava 3, 8, vermelho e castanho. A única maneira de verificar a veracidade dessa afirmação é retornar $P$ e não- $Q$ (isto é, 8 e castanho).

O nosso experimento continha 8 problemas, mas eliminámos posteriormente um deles, por 0 material ser muito diferente dos outros e ter provocado confusão. Os sete problemas que considerámos válidos envolviam atletas de algum desporto e algum equipamento ou instrumento, por exemplo, "Se tem Romário de um lado, do outro tem a camisa do Flamengo". Em cada grupo de 16 sujeitos com o mesmo nível de literacia, metade deles não eram informados se respondiam bem ou mal, e a outra metade recebia um feedback corretivo em caso de resposta incorreta.

Sem feedback, o desempenho foi muito mau, tal como descrito na literatura, inclusivamente para os letrados. Com feedback, o grupo letrado mostrou bom desempenho a partir do problema 2 e todos responderam corretamente a partir do problema 4; o semiletrado só começou a melhorar a partir do problema 3, mas vários continuaram a ter dificuldades e só no último ensaio todos responderam corretamente; e o iletrado só melhorou a partir do problema 5 e mesmo no último ensaio só 6 sujeitos fizeram a boa escolha apesar das ajudas prestadas nos problemas anteriores. Assim, muitos iletrados podem compreender o raciocínio dedutivo de tipo condicional, mas precisam de muita ajuda.

Mas o mais interessante é que um dos iletrados, justamente do grupo sem ajuda, jovem tratorista de 19 anos, respondeu bem aos problemas, tendo passado muito tempo perante o primeiro antes de responder e depois cada vez menos. No fim perguntámos como tinha feito e não soube explicar. Ele escolhia as duas cartas certas a partir de uma intuição válida, mas não foi capaz de explicar a regra, nem com palavras simples. Acertou sempre sem saber explicar. Não sendo letrado, não tinha maneira de pôr palavras sobre o seu raciocínio. No entanto, esta questão merece mais investigação, porque não sabemos se os letrados sem formação em lógica que acertam na resposta correta conseguem justificá-la nem que seja de maneira aproximativa.

\section{Resumindo e concluindo... provisoriamente}

As enormes desigualdades das sociedades humanas criadas pela apropriação individual dos bens materiais engendraram uma outra grande desigualdade, a da sua linguagem, e os dois tipos de 
desigualdade têm interagido de maneira tal que se aprofunda o fosso entre os extremos.

A linguagem das comunidades humanas não deve ter conhecido desigualdades importantes até à invenção da escrita. Esta, sendo na sua essência a materialização de um bem cognitivo, mas tendo-se tornado também um instrumento de domínio de muitos por alguns, transformou profundamente a linguagem e a cognição humanas e criou uma linguagem que vai de rica a pobre. A pobre também mudou, mas apenas através do contato com a rica é a dos iletrados -, enquanto a rica se desenvolveu de maneira surpreendente, quase inacreditável, a apreciar em particular na filosofia, nas ciências e na literatura e no seu impacto nas subsequentes invenções tecnológicas.

Uma contradição emergiu na sequência da invenção da escrita alfabética. A literacia alfabética permitiu, durante um século, $05^{\circ}$ da era cristã, a seguir à reforma política de Clisteres, que neutralizou o poder dos aristoi, os ricos proprietários, que o novo regime, a democracia, se tornasse viável pela participação rotativa dos cidadãos, ricos e pobres, designados por sorteio, à atividade política e ao governo da Ática, que obrigavam à aprendizagem da leitura e da escrita durante o exercício dessas funções. Havia, portanto, um círculo virtuoso entre a prática da democracia e o desenvolvimento da literacia. Isto, se considerarmos apenas os "homens livres" (10\% da população) e esquecermos as mulheres, os jovens de menos de 21 anos, assim como os escravos e os estrangeiros que contribuíam com o seu trabalho sem usufruírem do menor direito.

$\mathrm{Na}$ sequência de uma derrota militar, a queda do regime democrático, devida a um golpe que instaurou a ditadura, pôs fim àquele processo e a literacia retornou ao estatuto de bem cognitivo nas mãos dos ricos. Desde então, nunca mais houve democracia (à parte, isoladamente, em comunidades) e a literacia retornou ao papel que já tivera de instrumento de domínio e opressão da maioria por uma minoria. E assim chegámos aos dias de hoje. A literacia de alto nível, generalizada, universal, continua sendo uma condição da democracia e da garantia efetiva da igualdade de direitos.

Para que todos os indivíduos participem em iguais condições no governo democrático das sociedades humanas, é indispensável que todos eles possam ir além da literacia de base e desenvolvam a literacia crítica e argumentativa. Ler um texto é compreendê-lo (ler com o texto), identificar o que tem de errado, falso ou insuficiente (ler contra o texto), e superá-lo (ler além do texto). E escrever um texto é ser capaz não só de articular por escrito o seu pensamento, mas também de escutar o seu próprio texto para pôr à prova os fundamentos e a solidez das suas ideias e da sua argumentação. Este tipo de literacia pressupõe a apropriação das condições cognitivas que permitem verificar os fundamentos das afirmações, quaisquer que estas sejam, e a formulação, em total liberdade e responsabilidade, das ideias e propostas mais condizentes com a razão e com os princípios humanistas.

É possível instaurar nas sociedades humanas a autêntica democracia? Por que não seria? Como mais ou menos dizia um poeta, o letrado mais criativo de língua portuguesa, tudo vale a pena quando a alma não é pequena. Afinal, só depende de nós, e neste caso o nós somos nós todos, ricos, pobres e diversas classes intermediárias, letrados, iletrados e semiletrados. Mas a responsabilidade dos letrados desejosos de democracia é maior. E é obviamente para esses que escrevo.

Os governos não querem que o povo se instrua demasiado, que todo ele se torne uma massa de letrados críticos que se entendam para transformar o nosso mundo antes que pobres e ricos, todos desejosos de viver na Terra - embora alguns ricos sonhem em ir para Marte - acabem morrendo de morte lenta nesta Terra que vai perdendo o ar e arrostando cada vez mais frequentes catástrofes. Nesta Terra em que a linguagem letrada vai perdendo cada vez mais a sua riqueza e beleza, substituída por uma linguagem de celular (não é verdade que no Brasil, país de enormes desigualdades, pululam os não-letrados e os celulares?), e por uma linguagem gestual grosseira e violenta (levantar o polegar e 
apontar o index como uma arma, recolhendo os outros dedos, ah o gosto de dispara e matar...), não terá chegado agora o momento de dizer NÃO ao destino para que nos empurram o capitalismo financeiro e neoliberal e os seus agentes à cabeça dos Estados?

Pois em nome de quê devemos aceitar o que querem ou não querem os governos? Não terá chegado o momento de a grande massa dos letrados jovens estudantes organizarem um amplo movimento que crie espaços de liberdade no seio das instituições de educação, ligando-as entre si? E que, paralelamente, se una organicamente ao povo trabalhador, às comunidades e às minorias com objetivos próprios, para edificar uma educação popular letrada através do Brasil?

$E$ que, pelo seu lado, os linguistas e psicolinguistas, que estudam a linguagem e literacia e sabem a importância destas, deixem de consagrar todo o seu tempo a estudá-las, e percebam que estamos a debruçar-nos sobre o que pode tornar-se rapidamente cadáveres anunciados se não intervirmos na presente realidade social e política? Quem elege os idiotas perigosos - quase todos letrados, se bem que de vez em quando as classes ricas tenham de recorrer a semiletrados - que nos governam? É o povo, claro, o povo ludibriado, e dentro dele, também nós, os letrados. Somos todos nós e, coletivamente, não temos desculpa. Isso cria uma responsabilidade à qual nenhum de nós pode furtar-se. Os letrados que somos, tão ocupados a discutir o que é a recursão ou o que são as metáforas ou outras questões tão atrativas intelectualmente, têm, temos, uma missão urgente. Que cada grupo se mobilize no seu terreno, encarregando-se da alfabetização e da formação da em literacia crítica (eu diria "literacização") dos iletrados e semiletrados à sua volta!

Posto que os governantes não querem saber da educação, e muito menos do seu núcleo central, a literacia, Ihe reduzem as verbas em vez de aumentálas, e posto que perseguem os professores e os estudantes porque estes têm a sua liberdade e vontade próprias, a nossa missão urgente é organizarmos nós mesmos a educação à literacia em grande escala, desde a alfabetização até ao exercício do pensamento crítico que varrerá todas as fake news, e com elas os seus autores e mandatários, para o lixo, o lixo da História, e para que possamos escrever uma nova História, uma que seja linda, na qual seremos todos letrados e nos sentiremos bem.

\section{Referências}

BERGEN, B.; Chan Lau, T.T. Writing direction affects how people map space onto time. Frontiers in psychology, 3, 109, 2012.

BOVENS, M.; WILLE, A.. Diploma Democracy. The Rise of Political Democracy. Oxford: Oxford University Press, 2017.

CARY, L. A análise explícita das unidades da fala não adultos não alfabetizados. Dissertação de Doutorado. Universidade de Lisboa, 1988.

CORRÊA, V. R. Objeto direto nulo no português do Brasil. Tese de mestrado não publicada. UNICAMP, 1991.

DABROWSKA, E. The LAD goes to school. A cautionary tale for linguistics. Linguistics, 35, 735766, 1997.

DEHAENE, S.; COHEN, L.; MORAIS, J.; KOLINSKY, R. Illiterate to literate: behavioral and cerebral changes induced by reading acquisition. Nature Reviews Neuroscience, 16(4), 234, 2015.

DEHAENE, S.; PEGADO, F.; BRAGA, L.; VENTURA, P.; NUNES FILHO, P.; JOBERT, A.; DEHAENELAMBERTZ, G.; KOLINSKY, R.; MORAIS, J.; COHEN, L. How learning to read changes the cortical networks for vision and language. Science, 330(6009), 1359-1364, 2010.

FUHRMAN, O.; BORODITSKY, L. Cross-cultural differences in mental representations of time: Evidence from an implicit nonlinguistic task. Cognitive science, 34, 1430-1451, 2010.

GOULD, S.J. A nation of morons. New Scientist, 6 May 1982, pp. 349-352. (Nota: este artigo é um extrato editado do livro do mesmo autor, The Mismeasure of Man, publicado na semana anterior por W.W. Norton).

KATO, M.A. A gramática do letrado: Questões para a teoria grammatical. In: M.A. MARQUES, M. A.; KOLLER, E.; TEIXEIRA, J.; LEMOS, A. S. (Org.) Ciências da Linguagem: trinta anos de investigação e ensino. Braga, CEHUM: Universidade do Minho, 2005, p. 131-145. 
KOLINSKY, R.; CARY, L.; MORAIS, J. Awareness of words as phonological entities: The role of literacy. Applied Psycholinguistics, 8(3), 223-232, 1987.

KOLINSKY, R.; MORAIS, J. The worries of wearing literate glasses. L'Année Psychologique / Topics in Cognitive Science,118, 321-347, 2018.

KOLINSKY, R.; MORAIS, J.; COHEN, L.; DEHAENE, $S$. Les bases neurales de l'apprentissage de la lecture. Langue Française, 199, 17-33, 2018.

KOLINSKY, R.; VERHAEGHE, A.; FERNANDES, T.; MENGARDA, E.J.; GRIMM-CABRAL, L.; MORAIS, J. Enantiomorphy through the looking glass: Literacy effects on mirror-image discrimination. Journal of Experimental Psychology: General, 140(2), 210, 2011.

LIBERMAN, A. M.; COOPER, F. S.; SHANKWEILER, D. P.; STUDDERT-KENNEDY, M. Perception of the speech code. Psychological Review, 74, 431$461,1967$.

MORAIS, J.; CARY, L.; ALEGRIA, J.; BERTELSON, $P$. Does awareness of speech as a sequence of phones arise spontaneously? Cognition, 7, 323331, 1979.

MORAIS, J.; KOLINSKY, R. Phonological abilities in fully illiterate adults. In: PERRIN. D. (Ed.) Handbook of Poor Adult Reading: Wiley, 2020 (in press).

OCDE. Skills Matter. 2016b. http://dx.doi.org/10.1787/9789264258051-en

OECD PISA 2015 Results (Volume I): Excellence and Equity in Education, OECD Publishing, Paris, 2016a. http://dx.doi.org/10.1787/9789264266490en
OUELLET, M.; SANTIAGO, J.; ISRAELI, Z.; GABAY, $S$. Is the future the right time? Experimental psychology, 57, 308-314, 2010.

PATTAMADILOK, C.; MORAIS, J.; COLIN, C.; KOLINSKY, R. Unattentive speech processing is influenced by orthographic knowledge: Evidence from mismatch negativity. Brain and language, 137, 103-111, 2014.

READ, C.; YUN-FEI, Z.; HONG-YIN, N.; BAO-QING, $D$. The ability to manipulate speech sounds depends on knowing alphabetic writing. Cognition, 24, 31-44, 1986.

REIS, A.; GUERREIRO, M.; PETERSSON, M. A sociodemographic and neuropsychological characterization of the illiterate population. Applied Neuropsychology, 10, 191-204, 2003.

ROSER, M.; ORTIZ-OSPINA, E. Literacy. Our World in Data. 2016. https://ourworldindata.org/literacy

SCHOLES, R. J.; WILLIS, B. J. Age and education in oral language skills. Developmental Neuropsychology, 3; 239-248, 1987.

SWEENEY, A. Mental tests for immigrants. The North American Review, 215, 600, 1922.

YOUNG, K. Intelligence tests of certain immigrant groups. The Scientific Monthly (publicado pela American Association for the Advancement of Science), 15, 417-434, 1922.

ZIEGLER, J.C.; FERRAND, L. Orthography shapes the perception of speech: The consistency effect in auditory word recognition. Psychonomic Bulletin \& Review, 5, 683-689, 1998.

\section{COMO CITAR ESSE ARTIGO}

MORAIS, José. O que faz a diferença entre a linguagem rica e a linguagem pobre?. Signo, Santa Cruz do Sul, v. 44, n. 81, dez. 2019. ISSN 1982-2014. Disponível em: $<$ https://online.unisc.br/seer/index.php/signo/article/view/14574>. Acesso em: doi: https://doi.org/10.17058/signo.v44i81.14574. 